American Journal of Applied Sciences 6 (12): 2010-2017, 2009

ISSN 1546-9239

(C) 2009 Science Publications

\title{
Evaluation of Some Organic Pollutants Transport into the Shallow Groundwater and Surface Water of Jiaxing Landfill Area
}

\author{
${ }^{1}$ Souleymane Keita, ${ }^{1}$ Zhonghua Tang, ${ }^{1}$ Shaogang Dong and ${ }^{2}$ Yuehua Jiang \\ ${ }^{1}$ Department of Hydrogeology and Water Resources, School of Environment Studies, \\ China University of Geosciences, 430074 Wuhan, China \\ ${ }^{2}$ Nanjing Institute of Geological and Mineral Resources 210016 Nanjing China
}

\begin{abstract}
Problem statement: Hangjiahu regions belong to the Yangtze River Delta region in Zhejiang Province in China. The vast majority of this region is flat, so surface and groundwater both have a low flow rate. With the rapid economic development of the area, a large number of industrial and domestic garbage are generated. These landfill or garbage are exposed and stacked. Because of mismanagement of environment, the atmosphere under the leaching rainfall, results in harmful gases and leachate. A serious pollution of the atmosphere surrounding the dump, soil, surface water and groundwater occurred. By studying the area under different hydro geological conditions this groundwater pollution due to the landfill can be stopped and prevented. This research can also provide a scientific basis. Approach: Some samples were taken to some specific sampling points in order to do chemical analysis. A hydro geological investigation was done on the study area. By using all these data, groundwater pollution was evaluated and predicted through numerical simulation software: Groundwater Modeling System (GMS), from 2006-2007. Results: A total of six main organic pollutants were found in the entire study area including: toluene, dichloropropane, benzene, dichloroethane, chloroform and dichloromethane. There concentration increased form 2006 to 2007 and is higher in surface water than groundwater. Conclusion/Recommendations: Experimental and simulation results were compared and showed that close agreement between these two values were obtained. The application of ecological methods to remove harmful substances such as the cultivation of suitable plants is also necessary.
\end{abstract}

Key words: Organic pollutants, numerical simulation, groundwater, surface water, landfill

\section{INTRODUCTION}

This study was done by combining both deterministic and stochastic models as defined by Addiscott ${ }^{[1]}$.

The first to propose a similar model of advectiondispersion equation are Lapidus and Amundson ${ }^{[2]}$, they opened a prelude to the study of solute transport, but they did not give the model parameters derivation ways and specific meaning.

In 1954, Scheidigg will use Lapidus to the threedimensional expansion of the equation, bearing in mind at the time of the solute transport in the role of mechanical dispersion, so that the theoretical study of solute transport in a step forward.

In 1956, Rifai used Scheidigg on basic research results, but also takes into account the molecular diffusion of solute transport role and the introduction of the concept of dispersion (hydrodynamic dispersion coefficient and pore water velocity ratio $\alpha=\mathrm{D} / \mathrm{V}$ ), so that solute migration theory is used for more depth of groundwater.

Between 1961-1962 Nielson and Biggar ${ }^{[3,4]}$ based on a series of experiments, made easy mixed replacement theory, consider the flux of solute by convection, diffusion and dispersion caused by the combined effects and theoretically set up a convection dispersion equation. According to the experimental results, Lapidus, Shceidegg and Nielson's model is a comparative analysis of the results and shows that the convection dispersion equation better describes the conservative substances in porous media.

Desimone et al. ${ }^{[18]}$ Cleary and Adrain ${ }^{[6]}$, obtained the same results with different boundary conditions of the analytical solution ${ }^{[5]}$. With the popularization of computers, numerical methods are used to solve many solute transport problems ${ }^{[22]}$.

In 1980, Dasgupta et al. ${ }^{[7]}$, set up a chemical reaction groundwater solute transport model and simulated a leachate migration and transformation of

Corresponding Author: Souleymane Keita Department of Hydrogeology and Water Resources, School of Environment Studies, China University of Geosciences, 430074 Wuhan, China. 
iron ions from a garbage in Miami in the United States. Morrison et al. ${ }^{[8]}$, set up the value of uranium and iron six interaction reaction-migration model to analyze the reaction of iron hydroxides walls of hexavalent uranium in groundwater. Toride and Leij ${ }^{[9]}$ set up for stable linear filter down and primary sport of the ConvectionDiffusion Equation (CDE) model Absorption; Flury ${ }^{[10]}$ the solute degradation and adsorption process and the relationship between soil depth using a generalized function and experimental data authentication; Pachepsky et al. ${ }^{[11]}$ set up a description of the different soil moisture and reflect the fractal characteristics of medium convection-diffusion equation. In Stewart and Loague $^{[12]}$ set up a TTFs (type transfer functions) model Fresno, California United States east of the regional DBCP (dibromo-chloropropane) on the impact of groundwater quality assessment of a simulation. Karapanagioti et $a l^{[13]}$ taking into account evaporation, dispersion, adsorption and degradation established aquifer contaminant transport model of multi-component mixtures. Vanderborght and Vereecken ${ }^{[14]}$ for pesticides and salt transmission prediction study will describe the material in the solid and liquid two states under the reaction function with convection-combining the dispersion equation and application.

The study area overview: Hangzhou-Jiaxing-Huzhou Taihu Lake Basin is located in the southeastern region of China in Zhejiang province (Fig. 1). The geographical coordinates are: Longitude between $120^{\circ} 00^{\prime}$ ' and $121^{\circ} 16^{\prime}$ latitude between $30^{\circ} 13^{\prime}$ and $31^{\circ} 02$ ', for an area of about $6490 \mathrm{~km}^{2}$.

Ground elevation is between 1-7 m. In the Western Part, there is a sporadic distribution of residual hill with an average elevation of $100 \mathrm{~m}$.

The study area is located in subtropical monsoon climate zone with four seasons. The annual average temperature $15.7-16.2^{\circ} \mathrm{C}$. Average precipitation over the years is between $1140-1350 \mathrm{~mm}$.

The average surface evaporation is $910 \mathrm{~mm} \mathrm{year}^{-1}$ with an average of $80 \%$ of relative humidity.

The area occupied by surface water is of $679 \mathrm{~km}^{2}$ (10.5\% of total area).

Jiaxing region is densely populated and economically developed. The land known as the "land of fish and rice" is fertile and rich $(9.31 \%$ of Zhejiang Province).

The study area's population is $19.35 \%$ of Zhejiang Province for a gross domestic product accounted of $30.64 \%$ (Table 1).

Jiaxing city landfill basic information: Jiaxing landfill is surrounded by rivers (Fig. 2). Landfill average altitude is about $25 \mathrm{~m}$ and the elevation throughout the region is between $4.2-2.0 \mathrm{~m}$. The main aquifer layer is fine powder of sand (Fig. 3). And there is no large-scale exploitation of water resources in the region.

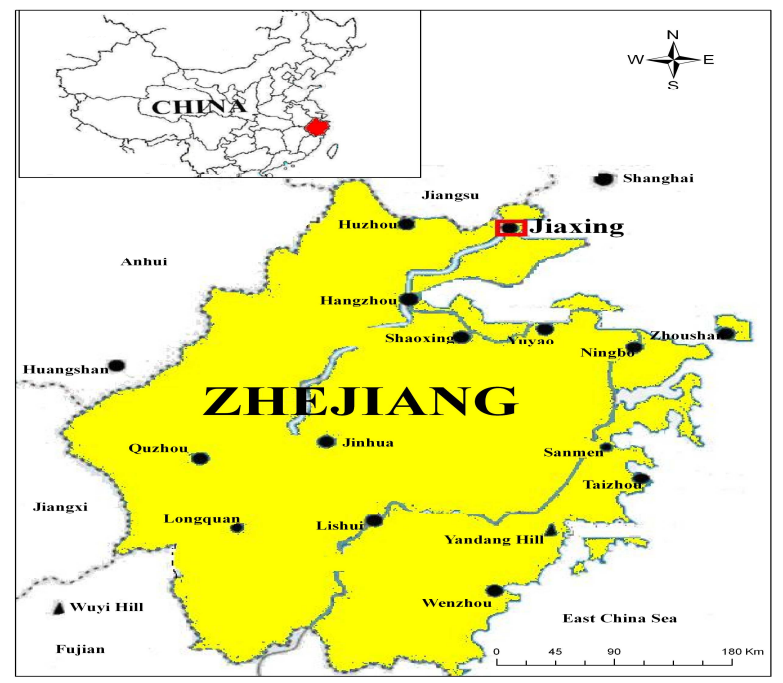

Fig. 1: Location of the study area
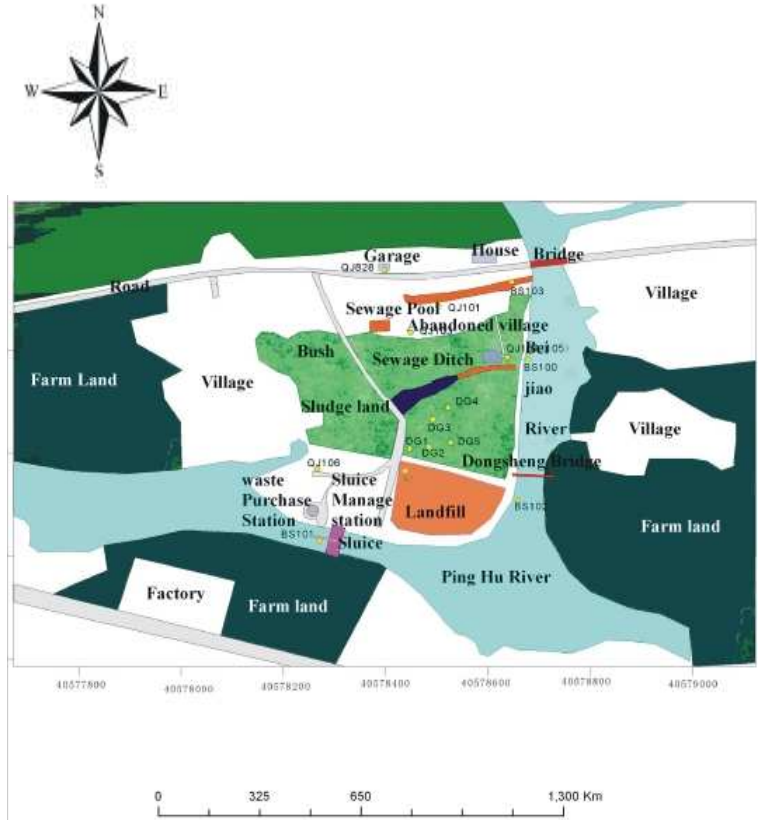

Fig. 2: Jiaxing Landfills Overview map with the sampling points

Table 1: Socio-economic profiles (by the end of 2004 statistical data)

\begin{tabular}{lcrrr}
\hline Region & $\begin{array}{l}\text { Population } \\
\text { (million) }\end{array}$ & $\begin{array}{l}\text { Land } \\
\left(\mathrm{km}^{2}\right)\end{array}$ & $\begin{array}{l}\text { Arable } \\
\text { land } \\
(1000 \mathrm{ha})\end{array}$ & $\begin{array}{l}\text { Gross domestic } \\
\text { product } \\
\text { (billion RMB) }\end{array}$ \\
\hline Hangzhou city & 4.0159 & 3068 & 98.327 & 1949.41 \\
Huzhou city & 1.5032 & 2502 & 72.734 & 388.45 \\
Jiaxing city & 3.3394 & 3915 & 210.840 & 1107.15 \\
Province & 45.7722 & 101800 & 1594.920 & 11243.00 \\
\hline
\end{tabular}



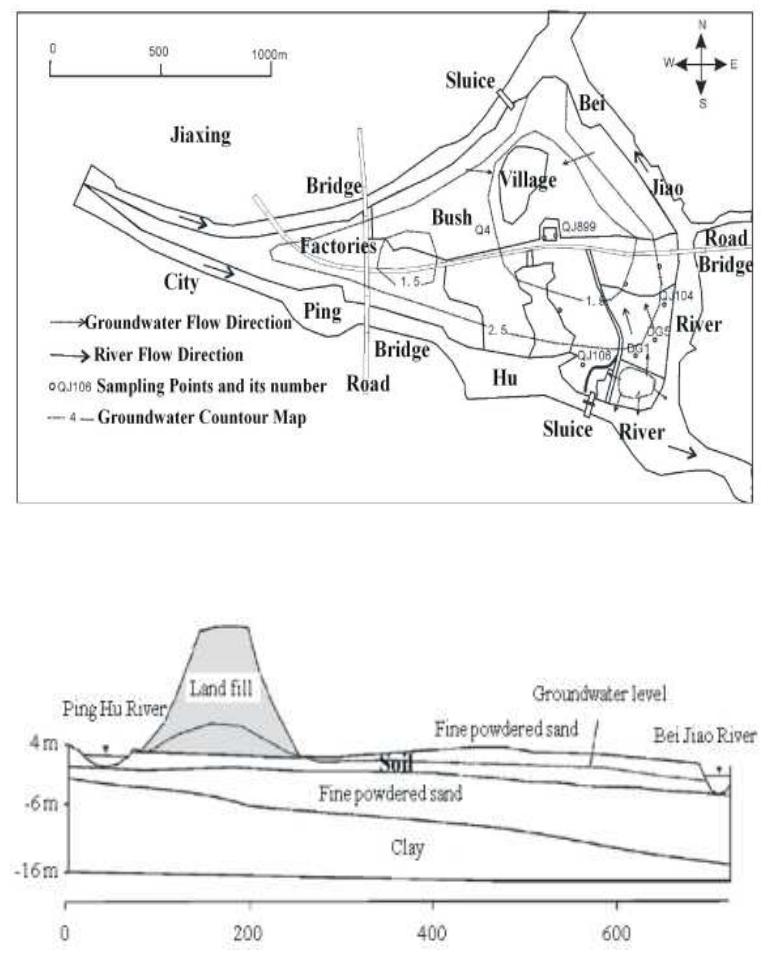

Fig. 3: Study area conceptual model

\section{MATERIALS AND METHODS}

This study was done in two important phases: investigations and numerical simulation.

Investigations: Landfill leachate is generated by water or other liquids passing through the trash $\mathrm{h}^{[15]}$. Landfill leachate comes mainly from precipitation, surface water, groundwater intrusion into landfill and litter moisture ${ }^{[16,17]}$.

Some soil and water samples were used for experimental analysis in November 2007 and September 2008. It was about: Absorption, adsoption, desorption,... and to get the main organic and inorganic pollutants in the study area.

The experiments were done at China University of Geosciences (Wuhan), School of Environmental Studies Laboratory of the solute transport. At the trial period, the indoor temperature was 23-25 degrees Celsius.

The model: To predict the solute transport we needed to solve simultaneously the groundwater flow in unconfined aquifer and the solute transport equations ${ }^{[19-21]}$ :

\section{Groundwater flow:}

$$
\begin{aligned}
& \int \mu \frac{\partial \mathrm{H}}{\partial \mathrm{t}}=\frac{\partial}{\partial \mathrm{x}}\left[(\mathrm{H}-\mathrm{B}) \mathrm{K} \frac{\partial \mathrm{H}}{\partial \mathrm{x}}\right] \\
& +\frac{\partial}{\partial y}\left[(H-B) K \frac{\partial H}{\partial y}\right]+W-P(x, y \in D) \\
& \left\{\left.\mathrm{H}\left(\mathrm{x}_{0}, \mathrm{y}_{0}, \mathrm{t}\right)\right|_{\mathrm{t}=\mathrm{t}_{0}}=\mathrm{H}_{0}\left(\mathrm{x}_{0}, \mathrm{y}_{0}, \mathrm{t}_{0}\right) \quad(\mathrm{x}, \mathrm{y}) \in \mathrm{D}\right. \\
& \left.\mathrm{H}(\mathrm{x}, \mathrm{y}, \mathrm{t})\right|_{\Gamma_{1}}=\mathrm{H}_{1}(\mathrm{x}, \mathrm{y}, \mathrm{t}) \quad(\mathrm{x}, \mathrm{y}) \in \Gamma_{1}, \mathrm{t}>0 \\
& \left.(\mathrm{H}-\mathrm{B}) \mathrm{K} \frac{\partial \mathrm{H}}{\partial \mathrm{n}}\right|_{\Gamma_{2}}=-\mathrm{q}(\mathrm{x}, \mathrm{y}, \mathrm{t}) \quad(\mathrm{x}, \mathrm{y}) \in \Gamma_{2}, \mathrm{t}>0
\end{aligned}
$$

\begin{tabular}{|c|c|}
\hline $\mathrm{K}$ & $=$ Permeability coefficient $\left(\mathrm{m} \mathrm{day}^{-1}\right)$ \\
\hline & $\begin{aligned}= & \text { Rock aquifer specific } \\
& \text { yield(dimensionless) }\end{aligned}$ \\
\hline$H\left(x_{0}, y_{0}, t\right)$ & $=$ Unconfined aquifer water level $(\mathrm{m})$ \\
\hline$B(x, y)$ & $=$ Aquifer Bottom elevation $(\mathrm{m})$ \\
\hline $\mathrm{H}_{0}\left(\mathrm{x}_{0}, \mathrm{y}_{0}, \mathrm{t}_{0}\right)$ & $=$ The initial flow field $(\mathrm{m})$ \\
\hline $\mathrm{H}_{1}(\mathrm{x}, \mathrm{y}, \mathrm{t})$ & $\begin{aligned}= & \text { A class of the border on the water } \\
& \text { level }(\mathrm{m})\end{aligned}$ \\
\hline$N$ & 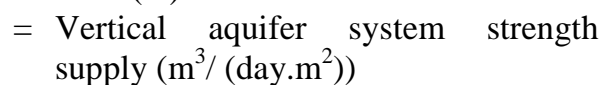 \\
\hline & $\begin{array}{l}=\text { Water supply and agricultural } \\
\text { production intensity }\left(\mathrm{m}^{3} /\left(\mathrm{d} \cdot \mathrm{m}^{2}\right)\right)\end{array}$ \\
\hline $\left.0, \mathrm{y}_{0}, \mathrm{t}\right)$ & II on the border of the flow $\left(\mathrm{m}^{3} /(\mathrm{dm})\right)$ \\
\hline
\end{tabular}

Where:

\section{Solute transport:}

$$
\begin{cases}\mathrm{R}_{\mathrm{d}} \frac{\partial \mathrm{C}}{\partial \mathrm{t}}=\mathrm{D}_{\mathrm{L}} \frac{\partial^{2} \mathrm{C}}{\partial \mathrm{x}^{2}}+\mathrm{D}_{\mathrm{T}} \frac{\partial^{2} \mathrm{C}}{\partial \mathrm{y}^{2}}-\mathrm{v}_{\mathrm{x}} \frac{\partial \mathrm{C}}{\partial \mathrm{x}}-\mathrm{v}_{\mathrm{y}} \frac{\partial \mathrm{C}}{\partial \mathrm{y}} & (\mathrm{x}, \mathrm{y}) \in \mathrm{D}, \mathrm{t}>0 \\ \mathrm{C}(\mathrm{x}, \mathrm{y}, 0)=\mathrm{C}_{0}(\mathrm{x}, \mathrm{y}) & (\mathrm{x}, \mathrm{y}) \in \mathrm{D} \\ \left.\mathrm{C}(\mathrm{x}, \mathrm{y})\right|_{\mathrm{B} 1}=\mathrm{f}_{1}(\mathrm{x}, \mathrm{y}) & (\mathrm{x}, \mathrm{y}) \in \mathrm{B} 1 \\ -\left.\mathrm{D} \frac{\partial \mathrm{C}}{\partial \mathrm{x}_{\mathrm{j}}} \mathrm{n}_{\mathrm{i}}\right|_{\mathrm{B} 2}=\mathrm{f}_{2}(\mathrm{x}, \mathrm{y}, \mathrm{t}) & (\mathrm{x}, \mathrm{y}) \in \mathrm{B} 1\end{cases}
$$

Where:

$\mathrm{C}_{0}(\mathrm{x}, \mathrm{y})=$ The initial concentration of pollutants $\left(\mathrm{mg} \mathrm{L}^{-1}\right)$

$\mathrm{f}_{1}(\mathrm{x}, \mathrm{y}, \mathrm{t})=$ To set the boundary concentration $\left(\mathrm{mg} \mathrm{L}^{-1}\right)$ $\mathrm{f}_{2}(\mathrm{x}, \mathrm{y}, \mathrm{t})=$ Gives the boundary diffusion flux (mg.m2.t-1)

D = Hydrodynamic dispersion coefficient $\left(\mathrm{m}^{2}\right.$ day $\left.^{-1}\right)$

$\mathrm{R}_{\mathrm{d}} \quad=$ Pollutant retardation factor

Numerical simulation: The results of these investigations have been used as input into a Groundwater Modeling System (GMS) to make simulation (by solving the model equations) in order to understand and to predict water pollution. Groundwater 
Modeling System (GMS) is a software made by Brigham Young University in the United States of America and US Army.

Geographic Information System (GIS) also has been used to output maps.

The study area covers $1.7 \mathrm{~km}^{2}$, it is surrounded by three rivers and these rivers are cutting an unconfined aquifer. Landfill site is in south-east corner of the study area, it covers an area of $0.21853044 \mathrm{~km}^{2}$. The accumulation of ground above the average thickness is about $25 \mathrm{~m}$. According to the geological conditions and hydro-geological conditions, the thickness of the upper soil layer is about $0.2-3 \mathrm{~m}$; the lower fine powdered sandy layers thickness is 3-7 $\mathrm{m}$ (Fig. 3). They are two Anisotropic and homogeneous structures. The rivers served as a constant head boundary.

According to the characteristics of groundwater flow, the area was summarized into a three-dimensional non-steady groundwater flow system.

There was two main periods: Wet period and dry period. And the source/sink are: Infiltration, precipitation, evapotranspiration irrigation, exploitation (water supply). The main parameters are in Table 2 and the rainfall distribution in Fig. 4.

The simulation used a discrete rectangular grid spacing. In the $\mathrm{X}$ direction the distance between two nodes is $43 \mathrm{~m}$ while in the $\mathrm{Y}$ direction the grid spacing is $14 \mathrm{~m}$. In the $\mathrm{Z}$ direction, based on borehole data in this area and the hydro-geological profiles, there are two layers (Fig. 5). So there is at all 2892 cells (1446/layer).

Table 2: Hydrogeological simulation parameter table

\begin{tabular}{lll}
\hline Parameters & 1st layer & 2nd layer \\
\hline The level of permeability coefficient $\left(\mathrm{m} \mathrm{day}^{-1}\right)$ & 0.0800 & 0.46000 \\
Degree of gravity water supply & 0.1000 & 0.30000 \\
Degree of flexibility in water supply $(1 / \mathrm{m})$ & 0.0001 & 0.00003 \\
\hline
\end{tabular}

*Note: These data were get from Jiaxing water conservancy and hydropower survey and design Institute

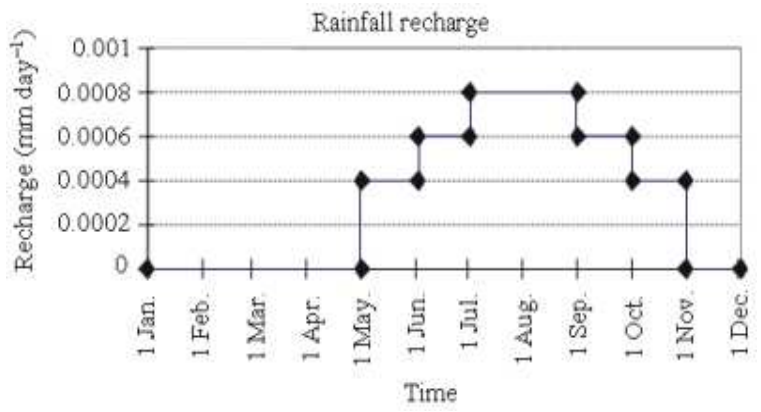

Fig. 4: The average rainfall distribution on the study area
The landfill was opened in 1996 and closed in 2007, but the simulation time is from January 1996 to February 2011. And time unit is one day. Seven observation wells: QJ104, QJ106, QJ899, DG1, DG2, DG3 and DG5 are chosen according to hydrogeological conditions.

This study used Calibration model based on previous hydro-geological conditions and the pumping test data to develop a set of initial parameter values. And the first time step values are got from these values, the second time step values from the first time step values (Fig. 6).

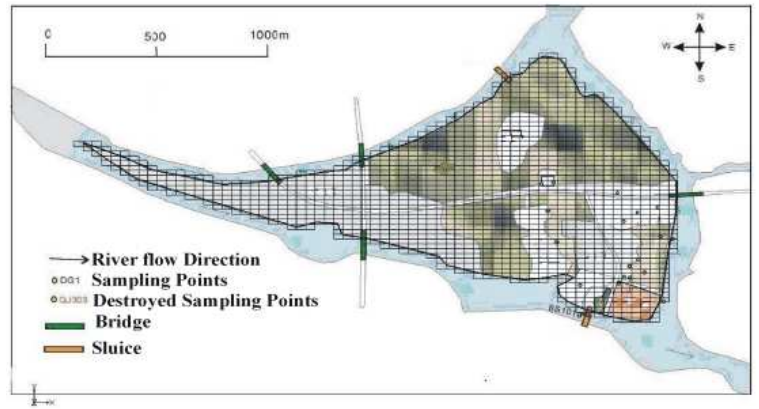

Fig. 5: Mesh of study area map
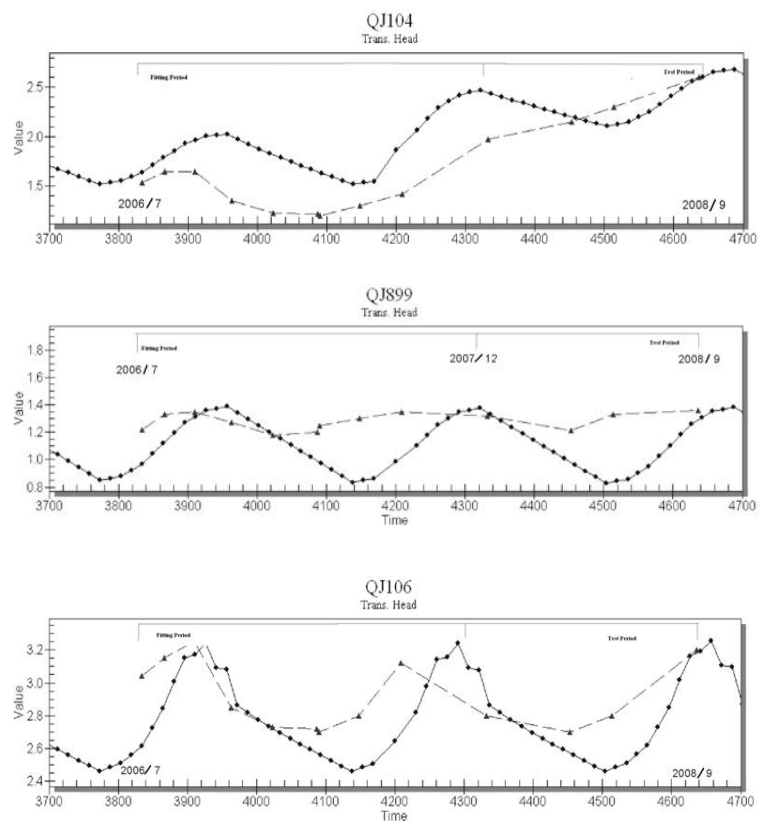

$\underset{\substack{\mathrm{DGG} \\ \text { Tiana Head }}}{\mathrm{DH}}$

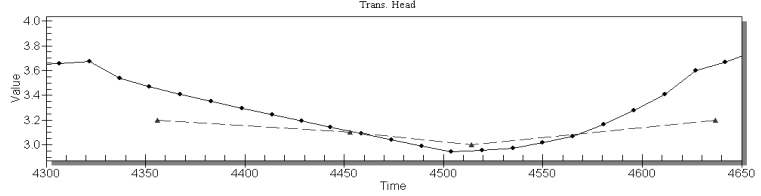



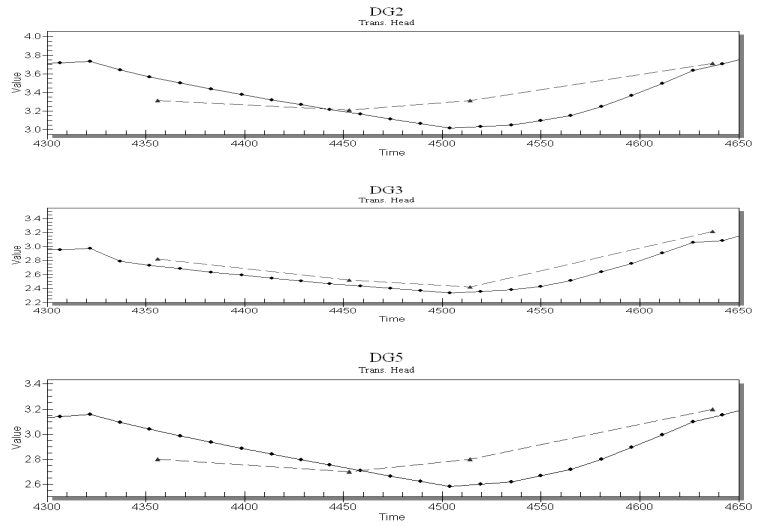

Fig. 6: Observation wells data set. *: Triangle for the observed data; **: Dot for interpolated data

\section{RESULTS}

A total of six relatively high concentration pollutants were found: Toluene, dichloropropane, benzene, dichloroethane, chloroform and dichloromethane.

In November 2007, the landfills PH value was 7.9. Figure 7 shows the trend of the organic pollutant between 2006 and 2007. In landfill site all pollutant concentration are below $1 \mu \mathrm{g} \mathrm{L}^{-1}$ except toluene in 2007(Fig. 7a*) where it is $6.5 \mu \mathrm{g} \mathrm{L}{ }^{-1}$. In the entire study area, pollutant concentrations are also generally below $1 \mu \mathrm{g} \mathrm{L}{ }^{-1}$ except dichloroethane in 2006 and 2007 (Fig. 7d and $\mathrm{d}^{*}$ ). And the highest concentration of pollutant found in the whole study area is the dichloroethane's which were above $700 \mu \mathrm{g} \mathrm{L}^{-1}$ in some sampling points (Fig. 7d*). However no dichloropropane was found in the entire study area in 2006.

The concentration of different pollutant found in the whole study area generally increased from 2006 to 2007.

\section{DISCUSSION}

By comparing the results of 2006 and 2007 six main organic pollutant were found in the entire study area including toluene, dichloropropane, benzene, dichloroethane, chloroform and dichloromethane:

- Toluene concentration in landfill leachate decreased from $0.65 \mu \mathrm{g} \mathrm{L}^{-1}$ in $2006-0.5 \mu \mathrm{g} \mathrm{L}^{-1}$ in 2007 and the toluene concentration is higher in surface water than groundwater in the study area (Fig. 7a and $\mathrm{a}^{*}$ ). This can be due to the attribution of news residences in this area after some other places demolition or to the lack of farm management and the reduction of pesticide spraying in the same period

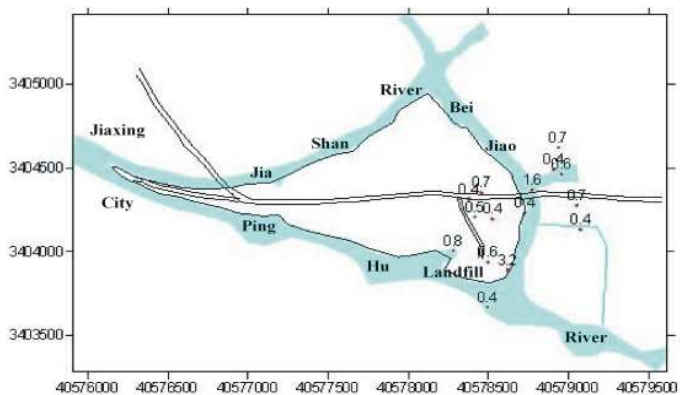

(a)

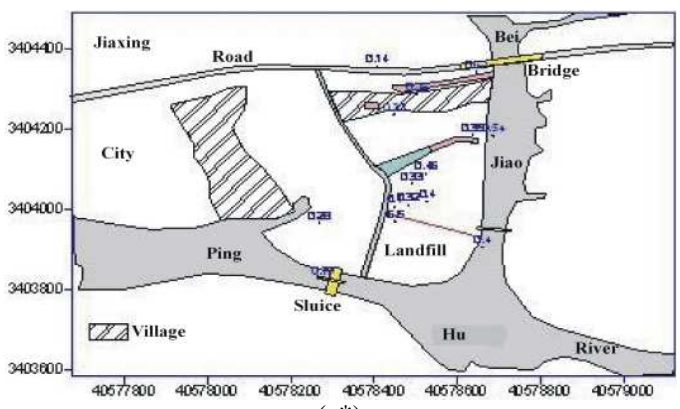

$\left(a^{*}\right)$

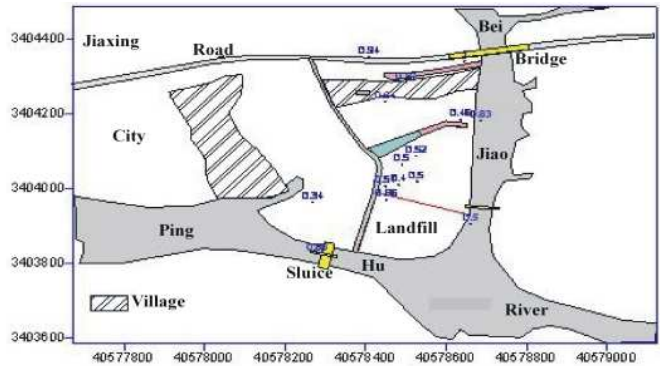

(b)

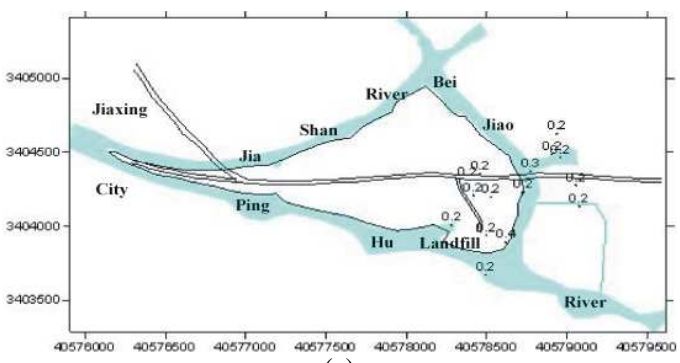

(c)

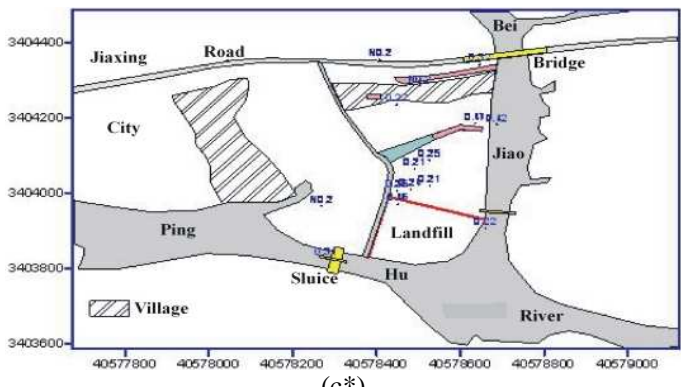

(c*) 


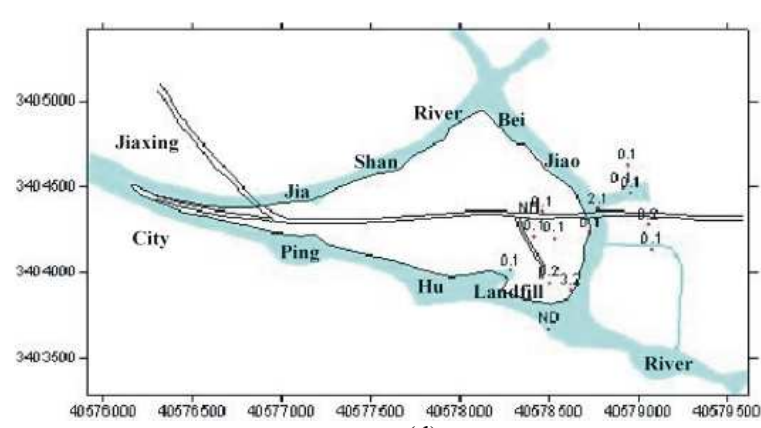

(d)

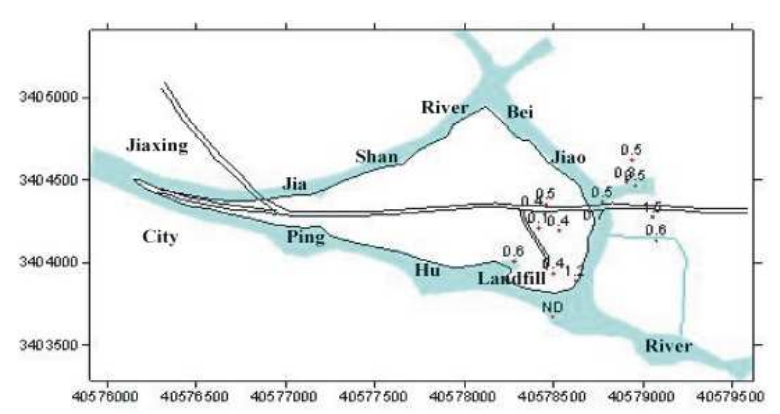

(e)

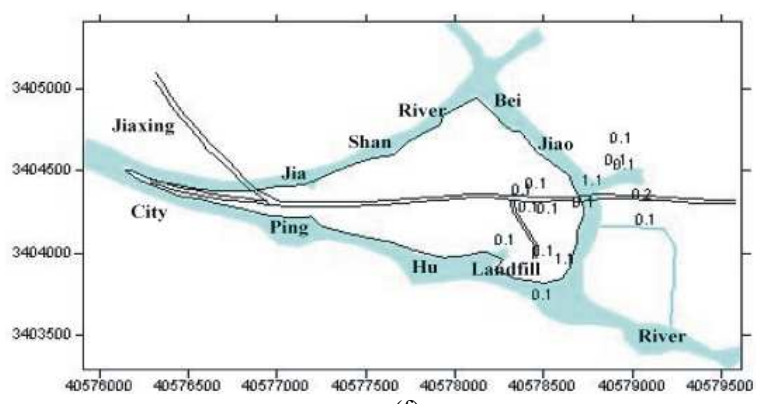

(f)

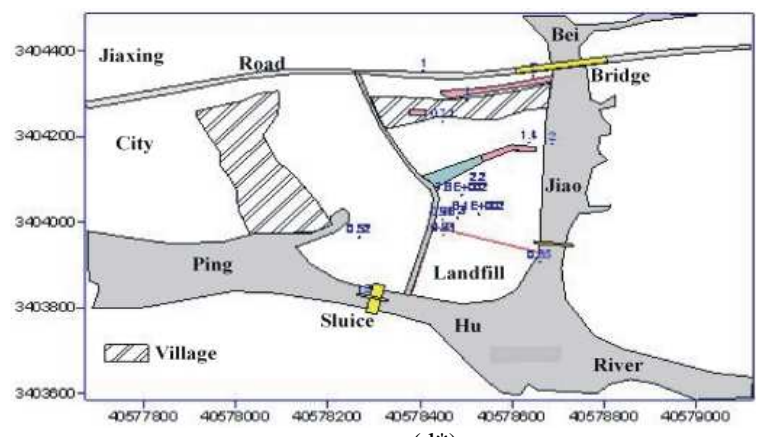

$\left(d^{*}\right)$

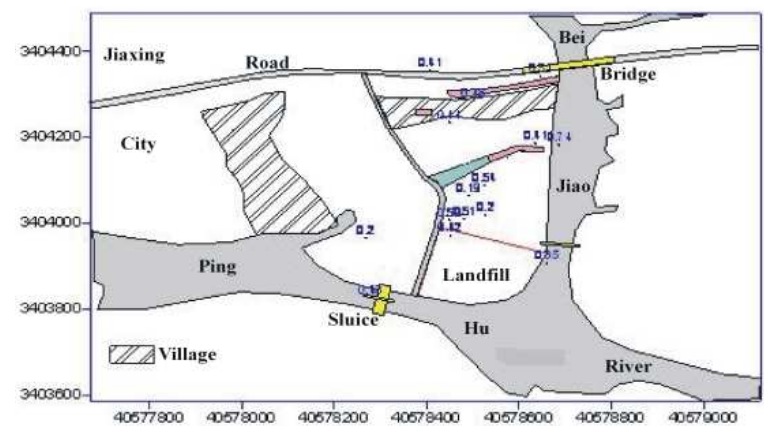

$\left(\mathrm{e}^{*}\right)$

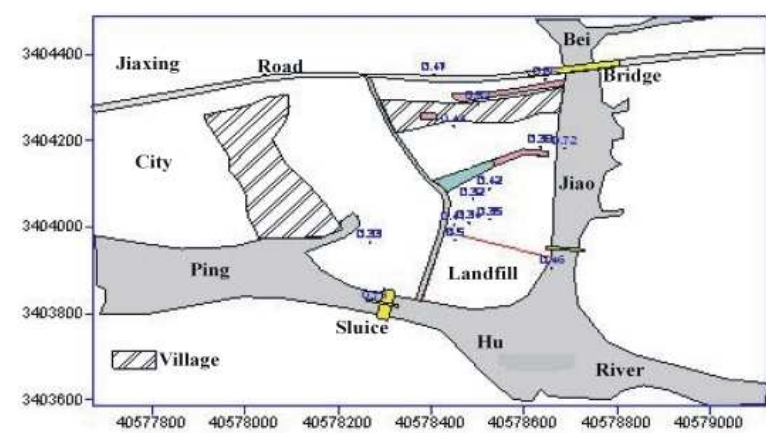

(f*)

Fig. 7: Changes in organic pollutants concentration $\left(\mathrm{mg} \mathrm{L}^{-1}\right)$ on Landfill site. (a) toluene in 2006; (a*) toluene in 2006; (b) dichloropropane in 2007; (c) benzene in 2006; ( $\left.\mathrm{c}^{*}\right)$ benzene in 2007; (d) dichloroethane in 2006; ( $\left.\mathrm{d}^{*}\right)$ dichloroethane in 2007; (e) chloroform in 2006; ( $\mathrm{e}^{*}$ ) chloroform in 2007; (f) dichloromethane in 2006; ( $\mathrm{f}^{*}$ ) dichloromethane in 2007

- No dichloropropane was detected in the entire study area in 2006. But in 2007 it concentration in landfill leachate was about $0.860 .5 \mu \mathrm{g} \mathrm{L}^{-1}$. And it was detected in almost the entire study area for a concentration varying from $0.34-0.94 .5 \mu \mathrm{g} \mathrm{L^{-1 }}$ (Fig. 7b). It higher concentrations were also found in surface water and on the upper reaches of the sewage plant so more attention needs to be pay to the sluice. But no scientific reason were not found yet to explain presence of the dichloropropane
- Benzene concentrations in landfill leachate increased from $0.2 \mu \mathrm{g} \mathrm{L}^{-1}$ in 2006-0.46 $\mu \mathrm{g} \mathrm{L}^{-1}$ in 2007. but benzene concentration in groundwater and surface water was relatively stable (About $\left.0.2 \mathrm{~g} \mathrm{~L}^{-1}\right)$ in the entire study area for the two years (Fig. 7c and $\mathrm{c}^{*}$ )

- Dichloroethane concentration in landfill leachate increased from $0.2 \mu \mathrm{g} \mathrm{L}^{-1}$ in $2006-0.93 \mu \mathrm{g} \mathrm{L}^{-1}$ in 2007. And an overview of the whole study area showed a very important increase in this period (Fig. 7d and $\mathrm{d}^{*}$ ) 
- Landfill leachate concentration in chloroform is relatively stable (about $0.4 \mu \mathrm{g} \mathrm{L}^{-1}$ in 2006 and 2007). The concentrations were from sewage ditch, the sluice and surface water in the whole study area (Fig. 7e and $\mathrm{e}^{*}$ )

- Landfill leachate concentration in dichloromethane has significantly increased. In fact from $0.1 \mu \mathrm{g} \mathrm{L}{ }^{-1}$ in 2006, it reached $0.501 \mu \mathrm{g} \mathrm{L}^{-1}$ in 2007. And it had almost the same concentration every where in the study area in 2006, but it concentration increased significantly one year later in the entire study area (Fig. 7f and f*)

- The exploitation of shallow groundwater is mainly from local residents. In recent years, because of groundwater pollution they can not continue to increase consumption

This landfill was not a sanitary landfill because it did not have any protection system at the bottom and the top. There was no isolation from the entry of oxygen and rainfall infiltration; so that increased leachate production. The hydrogeological structure was not indicated for landfill therefore surface and groundwater are polluted.

\section{CONCLUSION}

Jiaxing landfill has been capped and transformed into a park, but its groundwater and surface water pollution will continue for many years. Anti-seepage curtain must be built to prevent the leakage of landfill leacheate. The application of ecological methods to remove harmful substances such as the cultivation of suitable plants is also necessary.

\section{ACKNOWLEDGEMENT}

This research was supported by China Scholarship Council and China University of Geosciences, School of Environmental Studies Wuhan China. The authors wish to thank The Hydrogeology and Water Resources Department of the School of Environmental Studies of China University of Geosciences in Wuhan China and the China Scholarship Council for their support.

\section{REFERENCES}

1. Addiscott, T.M. and R.J. Wagenet, 1985. Concepts of solute leaching in soil. A review of modeling approaches. J. Soil Sci., 36: 411-424. DOI: 10.1111/j.1365-2389.1985.tb00347.x

2. Lapidus, L. and N.R. Amundson, 1952. Mathematics of adsorption in Beds. J. Phys. Chem., 56: 984-988. DOI: 10.1021/j150500a014
3. Nielsen, D.R. and J.W. Biggar, 1961. Miscible displacement in soils: I experimental information. Soil Sci. Soc. Am. Pro, 25: 1-5. http://soil.scijournals.org/cgi/content/abstract/25/1/ 1

4. Nielsen, D.R. and J.W. Biggar, 1962. Miscible displacement in soils: III theoretical consideration. Soil Sci. Soc. Am. Pro., 26: 216-221. http://soil.scijournals.org/cgi/content/abstract/26/3/ 216

5. Viotti, P., M. Petrangeni Papili, N. Straqualursi and C. Gamba, 2005. Contaminant transport in an unsaturated soil: Laboratory tests and numerical simulation model as procedure for parameters evaluation. Ecol. Model., 182: 131-148. DOI: 10.1016/j.ecolmodel.2004.07.014

6. Cleary, R.W. and D.D. Adrain, 1973. Analytical solution of the convective-dispersive equation for cation adsorption in soils. Soil Sci. Soc. Am. Proc., 37: 197-199.

http://soil.scijournals.org/cgi/content/abstract/37/2/ 197

7. Dasgupta, D., S. Sengupta, K.V. Wong and N. Nemerow, 1984. Two-dimensional timedependent simulation of contaminant transport from a landfill. Applied Math. Model., 8: 203-210. DOI: 10.1016/0307-904X (84)90091-X

8. Morrison, S.J., V.S. Tripathi and R.R. Spangler, 1995. Coupled reaction/transport modeling of a chemical barrier for controlling uranium (VI) contamination in groundwater. J. Contam. Hydrol., 17: 347-363. DOI: 10.1016/0169-7722 (94)00040$\mathrm{O}$

9. Toride, N. and F.J. Leij, 1996. Convective2Dispersive St ream tube model for field-scale solute transport: I moment analysis. Soil Sci. Soc. Am. J., 60: 342-352. http://cat.inist.fr/?aModele $=$ afficheN\&cpsidt $=3040$ 892

10. Flury, M., 1998. Analytical solution for solute transport with depth dependent transformation or sorption coefficients. Water Resour. Res., 34: 2931-2937.

http://akasha.wsu.edu/ flury/theses_articles/analyti cal.pdf

11. Pachepsky, Y.A., J.W. Craeford and W.J. Rawls, 1999. Fractal models in soil science. Geoderma, 88: 137-164.

12. Stewart, I.T. and K. Loague, 1999. A type transfer function approach for regional-scale pesticide leaching assessments. J. Environ. Qual., 28: 378-387. http://jeq.scijournals.org/cgi/content/abstract/28/2/ 378 
13. Hrissi K. Karapanagioti, Chris M. Gossard, Keith A. Strevett, Randall L. Kolar and David A. Sabatini, 2001. Model coupling intraparticle diffusion/sorption, nonlinear sorption and biodegradation processes. Contamin. Hydrol., 3: 1-21. DOI: 10.1016/S0169-7722 (00)00179-0

14. Vanderborght, J. and H. Vereecken, 2007. Review of dispersivities for transport modeling in soils. Vadose Zone J., 6: 29-52. DOI: 10.2136/vzj2006.0096

15. Mark L. Brusseau, 1995. The effect of nonlinear sorption on transformation of contaminants during transport in porous media. J. Contamin. Hydrol., 17: 277-291. DOI: 10.1016/0169-7722 (94)00041$\mathrm{F}$

16. Zhihui Zhang and Mark L. Brusseau, 2004. Nonideal transport of reactive contaminants in heterogeneous porous media: 7. Distributeddomain model incorporating immiscible-liquid dissolution and rate-limited sorption/desorption. J. Contamin. Hydrol., 74: 83-103. DOI: 10.1016/j.jconhyd.2004.02.006

17. Johnson, G.R., K. Gupta, D.K. Putz and D.K. Putz, 2003. The effect of local-scale physical heterogeneity and nonlinear, rate-limited sorption/desorption on contaminant transport in porous media. J. Contamin. Hydrol., 64: 35-58. DOI: 10.1016/S0169-7722 (02)00103-1
18. Desimone, L.A., B.L. Howes and P.M. Barlow, 1997. Mass-balance analysis of reactive transport and cation exchange in a plume of wastercontaminated groundwater. J. Hydrol., 203: 228-249. DOI: 10.1016/S0022-1694 (97)00101-7

19. Jeonsang Hahn, 1996. Analysis of remedial alternatives of the Nanji Landfill, Korea. Environ. Geol., 28: 12-21. DOI: 10.1007/s002540050073

20. Despina Fatta, Achilleas Papadopoulos and Maria Loizidou, 1999. A study on the landfill leachate and its impact on the groundwater quality of the greater area. Environ. Geochem. Health, 21: 175190. DOI: 10.1023/A:1006613530137

21. Günes, S.T. and A. Turkman, 2007. Effect of a hazardous waste landfill area on groundwater quality. Air Water Soil Qual. Model. Risk Impact Assess., 2007: 281-292. DOI: 10.1007/978-1-40205877-6_26

22. Perrier, E., N. Bird and M. Rieu, 1999. Generalizing the fractal model of soil structure: The pore-solid fractal approach. Geoderma, 88: 137-164. DOI: 10.1016/S0016-7061(98)001025 